\title{
Comparison of Agroforests and Protected Forests in the East Usambara Mountains, Tanzania
}

\author{
Jaclyn M. Hall • Thomas W. Gillespie • \\ Moses Mwangoka
}

Received: 19 August 2009/ Accepted: 13 October 2010/Published online: 16 November 2010

(c) The Author(s) 2010. This article is published with open access at Springerlink.com

\begin{abstract}
Comparative studies on plant species richness, endemism, floristic composition, and structure between protected and unprotected forests are few in the Eastern Arc Mountains, one of the most biodiverse ecosystems in Africa. This study from one mountain range, the East Usambaras, examines floristic and structural tree data from 41-0.5 ha plots in four types of Eastern Arc forest: active agroforests, recently abandoned agroforests, mature secondary forest, and natural forest. Active agroforests had significantly lower tree species richness, endemic species richness, and stand density compared to natural and mature secondary forest. Recently abandoned agroforests contained a higher tree species richness, density, and tree height than active agroforests. Active and abandoned agroforests were dominated by an invasive tree, Maesopsis eminii. This tree species makes up a large percentage of the stems in active agroforests (26\%), recently abandoned agroforests (32\%), and in the canopy of mature secondary forests $\sim 30$ years post logging $(30 \%)$. Through time the increasing dominance of this non-native tree in active agroforests is a concern when considering the role of agroforests in a landscape scale conservation strategy.
\end{abstract}

J. M. Hall ( $ه)$

Department of Geography, University of Florida, P.O. Box 117315 3124, Turlington Hall, Gainesville, FL 32611-7315, USA

e-mail: jaclyn.hall@uclouvain.be

T. W. Gillespie

Department of Geography, UCLA, Los Angeles, CA, USA

M. Mwangoka

Tanzanian Forest Conservation Group, Morogoro,

Morogoro, United Republic of Tanzania
Keywords Usambara - Cardamom agroforestry · Forest conservation - Eastern Arc - Maesopsis eminii

\section{Introduction}

Tropical ecosystems are suffering from forest conversion and degradation at an increasing and alarming rate (Myers and others 2000; Achard and others 2002). Land managers and the international development community are currently searching for new strategies to implement conservation at a landscape level and are investigating the potential role of agroforests in environmental management and planning (Bhagwat and others 2008). Agroforestry, the practice of growing trees with agricultural crops, has been identified as an important strategy for conservation and development because it can generate additional sources of income, diversify food crops, and protect soils (Bishop and Landell-Mills 2002; Perfecto and others 2003; Turner and others 2007). The potential environmental services and livelihood benefits of agroforests in the tropics have attracted the attention of the conservation community and their donors as a possible method to enhance biodiversity and ecosystem services, especially the sequestering of carbon, while benefiting local livelihoods (Schroth and others 2004; Steffan-Dewenter and others 2007).

The Eastern Arc Mountains consist of 13 isolated mountain ranges and were included together with the adjacent coastal forests as one of the original biodiversity hotspots (Myers and others 2000). The Eastern Arc humid forests have high concentrations of species richness and high densities of strictly endemic species, including many endemic tree species (Burgess and others 2007). Previous research of the Eastern Arc Mountains estimates that the ecosystem has lost at least $70 \%$ of its natural forest and 
many of its narrowly endemic species are threatened with extinction (Newmark 1998, 2002; Brooks and others 2002; Hall and others 2009).

Cardamom agroforestry has been practiced in one Eastern Arc range, the East Usambaras, for 50 years. Cardamom agroforestry includes the thinning of canopy trees to create only $50 \%$ shade and the complete clearance of the lower strata of a once natural forest. This produces a tree covered agricultural system that may provide additional ecological services compared to sun grown agriculture, but has distinct differences from natural forest. Most research outside of protected forest in the region has focused on birds (Newmark 1991, 2006; Borghesio and others 2008) and there has been little quantitative research on the differences of tree species richness and endemism within different forest types in the East Usambaras since Hamilton and Bensted-Smith (1989).

Floristic surveys conducted in the mid 1990's in government forest reserves in East Usambaras found that species diversity and composition are significantly influenced by forest structure (Huang and others 2003). Determining how cardamom cultivation impacts the composition and structure of humid forest in the East Usambaras may lead to a better understanding of the role that traditional and non-traditional cardamom agroforests could play in a landscape scale conservation strategy for Eastern Arc forests. This information will help land managers and development organizations that are interested in encouraging more cardamom farming in the region. Traditional agroforestry systems use no chemical inputs and maintain a diverse canopy with native trees. Many studies have shown that traditional agroforestry practices will be more sustainable than sun-grown agriculture, yet they tend to produce lower yields and can require long fallow periods (Tscharntke and others 2005; Reyes and others 2006). The most intensely managed or non-traditional agroforests tend to have a non-native monospecific overstory and can have low biodiversity values similar to sun-grown agriculture or grazed pasture (Greenberg and others 1997; Philpott and Armbrecht 2006; Rotenberg 2007). With increasing globalization and escalating population in rural areas of the tropics, farmers may change their management strategies and increase intensity, including reducing shade tree density and diversity and increasing use of agrochemicals (Roth and others 1994; Moguel and Toledo 1999; Rappole and others 2003; Perfecto and others 2003).

Forests of the East Usambaras have also been heavily influenced by one invasive non-native tree, Maesopsis eminii (family Rhamnaceae), which is native to west and central Africa and the western parts of tropical East Africa (Binggeli 1989). Maesopsis eminii, a prolific seed producer, germinates abundantly in the infertile clay soils and is an aggressive colonizer in disturbed forests. As a pioneer species, it requires the light of large canopy gaps in order for seedlings to mature to saplings and beyond (Hall 1995). Once Maesopsis eminii becomes established in a disturbed area, its own seeds will no longer thrive under a closed canopy. Regeneration of native tree species then occurs underneath, provided native forest exists nearby to supply the seeds (Viisteensaari and others 2000). Maesopsis eminii seeds are spread throughout the landscape by hornbills and it becomes increasingly dominant in forests that are continually disturbed, such as agroforests.

We examine tree species richness, endemism, floristic composition, and structure of four classes of forest in the East Usambaras: active agroforests, recently abandoned agroforests, mature secondary forest, and natural forest. First, we identify if there are significant differences in tree species richness, endemism, and structure among the four forest classes. Second, we examine the presence and structure of the non-native tree, Maesopsis eminii, within each forest class. Third, we investigate how cardamom agroforests differ floristically and structurally from other forest classes.

\section{Methods}

Study Area

The East Usambaras, a mountain range consisting of $1200 \mathrm{~km}^{2}$ of low mountains and valleys in northeastern Tanzania, contain $360 \mathrm{~km}^{2}$ of the most biologically important forests of the Eastern Arc (Burgess and others 2007). Forest in East Usambaras ranges from humid forest at higher elevations to drier forest types and thickets on the foothills and coastal plain. The Eastern Arc forest, or submontane forest, is generally thought to begin around $800 \mathrm{~m}$ (Pócs 1976; Lovett and Wasser 1993). There remains $124 \mathrm{~km}^{2}$ of submontane forest $\geq 800 \mathrm{~m}$ in the East Usambaras, most of which is contained in two nature reserves, Amani Government Forest Reserve to the south and Nilo Government Forest Reserve to the north. In between these two reserves are patches of private forest owned by the tea estates, cardamom agroforests that have been in the past been traditionally managed, and a ridge of abandoned agroforests that is now protected under the new Derema Government Forest Reserve.

\section{Study Sites}

Forty-one study sites in the East Usambaras were surveyed in active agroforests $(n=9)$, recently abandoned agroforests $(n=13)$, mature secondary forest $(n=9)$, and natural 
forest $(n=10)$. Active agroforests incorporate cardamom (Elettaria cardamomum) under a canopy of native trees. Cardamom is one of the most expensive spices in the world and thrives under $40 \%$ to $50 \%$ evergreen shade on moist tropical slopes 600 to $1500 \mathrm{~m}$ in elevation (Reyes 2005). Recently abandoned agroforests occur where cardamom agroforests have been placed within a new protected area between 1996 and 2003, either into one of several village forest reserves or within the Derema Government Forest Reserve. Mature secondary forest was mechanically logged for a select number of species between the 1960's to the early 1980's (Hamilton and Bensted-Smith 1989). Although the process was ecologically damaging, the areas of logged forests that were sheltered from agricultural expansion through protection by one of the four tea estates have regenerated into impressive mature secondary forests. Because of the long historical presence of early modern humans in East Africa, the forests of the East Usambaras cannot be considered primary or virgin. Humans have long influenced the forests through their traditional (pre-industrial) activities, and can be considered part of the natural system. Therefore, protected forests that had not been logged were referred to as natural forest.

\section{Field Data Collection}

Floristic surveys were conducted in 2006 and 2007 in all four classes of forest in the East Usambaras (Fig. 1). Floristic composition and structural data were collected at each study site using a $50 \mathrm{~m}$ by $100 \mathrm{~m}$ plot in which all trees $\geq 20 \mathrm{~m}$ in height were surveyed. All trees $<20 \mathrm{~m}$ were surveyed in 10 subplots, designated using belt transects $50 \mathrm{~m}$ long and $2 \mathrm{~m}$ wide, spaced 10-m apart. Data on tree species, diameter at breast height $(\mathrm{dbh})$, and height in $5 \mathrm{~m}$ cohorts were collected for each stem that had a dbh $\geq 2.5 \mathrm{~cm}$. Height estimations were carried out by the field team after $>10 \mathrm{~h}$ of training using a clinometer on the edges of clearings. Training with the clinometer was repeated twice a month. Species identification was conducted at the National Herbarium of Tanzania. Voucher species have been deposited at the National Herbarium of Tanzania, the University of Florida and the Missouri Botanical Garden, and each has been entered into the TROPICOS database (www.tropicos.org). Endemic status was determined for each species by consulting the specimen distribution maps from the TROPICOS database. Endemism was defined in this study as strictly endemic to the Eastern Arc Mountains (Hamilton and Bensted-Smith 1989). The specimen distribution of each species was opened from the TROPICOS website into Google Earth and a species was determined to be endemic if all specimen occurrences were located only within one of the 13 Eastern Arc Mountains.

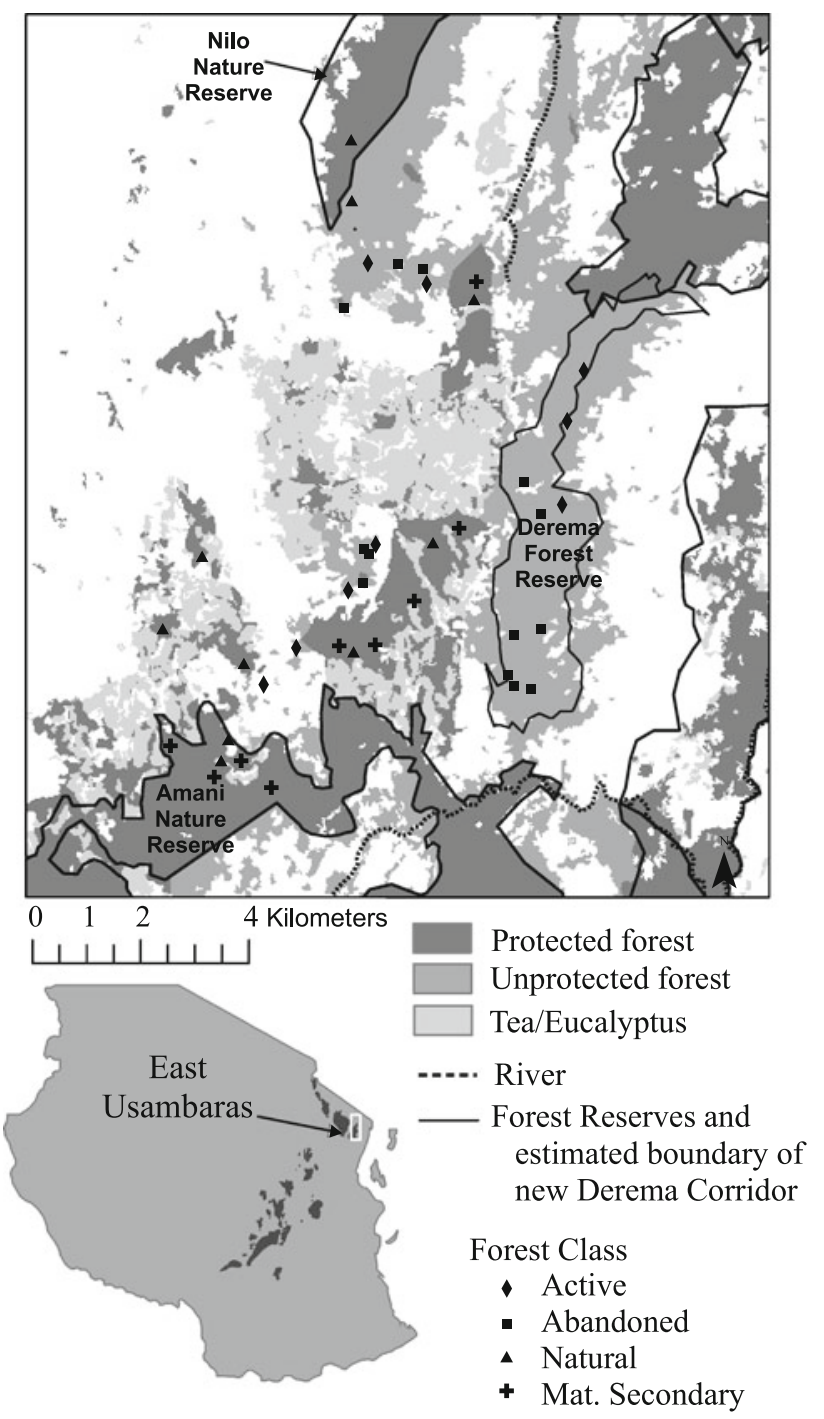

Fig. 1 East Usambara Mountains of Tanzania, one of the Eastern Arc Mountains. Land cover classification and study sites in central East Usambaras (created from Landsat ETM+ Jan. 30, 2003)

Data Analysis

The floristic data for mean number of species, endemic species, and number of trees in each height class for each surveyed plot had a normal distribution based on a onesample Kolmogorov-Smirnov test. A Single Factor ANOVA model was used to determine differences in tree species richness, family richness, and endemism among four forest classes. Post Hoc tests (Games-Howell for variables with significantly different variances, and Gabriel's test for variables with equal variances) were used to determine the statistical significance of differences of mean values of each variable among the forest classes to determine if the mean values for a 0.5 ha area are similar or different for the following variables: species richness, family richness, endemic richness, number of stems 
Table 1 Presences of seventeen species from the East Usambara Mountains that are endemic to the Eastern Arc
Forest type: Ac: Active; Ab: Abandoned; Ms: Mature Secondary; Nt: Natural

\begin{tabular}{llllll}
\hline Species endemic to Eastern Arc & Family & Ac (9) & Ab (13) & Ms (9) & Nt (10) \\
\hline Anisophyllea obtusifolia & Anisophyllaceae & 1 & 2 & 6 & 6 \\
Annickia kummeriae & Annonaceae & 4 & 7 & 4 & 3 \\
Beilschmiedia kweo & Lauraceae & 3 & 6 & 3 & 3 \\
Celtis wightii & Ulmaceae & 1 & 1 & & \\
Chassalia zimmermannii & Rubiaceae & & 1 & & 1 \\
Cynometra longipedicellata & Caesalpiniaceae & & & 3 & 2 \\
Englerodedron usambarense & Fabaceae & 1 & 1 & 3 & 3 \\
Greenwayodendron suaveolens subsp. & Annonaceae & 2 & 3 & 8 & 6 \\
$\quad$ usambaricum & Caesalpiniaceae & 2 & 6 & 6 & 8 \\
Isoberlinia scheffleri & Moraceae & 4 & 11 & 9 & 8 \\
Mesogyne insignis & Sapindaceae & & & 3 & 3 \\
Placodiscus amaniensis & Sapotaceae & 2 & 2 & 4 & 5 \\
$\begin{array}{l}\text { Pouteria adolfi-friedericii } \\
\text { Rytigynia lichenoxenos }\end{array}$ & Rubiaceae & & & 1 & 1 \\
Schefflerodendron usambarense & Caesalpiniaceae & & 1 & 4 & 3 \\
Uvariodendron oligocarpum & Annonaceae & & 1 & 3 & 1 \\
Uvariodendron usambarense & Annonaceae & & 1 & & 1 \\
Vitex amaniensis & Verbenaceae & & 1 & 2 & \\
\hline
\end{tabular}

$<20 \mathrm{~m}$, number of stems $\geq 20 \mathrm{~m}$, proportion of Maesopsis eminii stems $<20 \mathrm{~m}$ and $\geq 20 \mathrm{~m}$, and number of endemic trees $<20 \mathrm{~m}$ and $\geq 20 \mathrm{~m}$. The statistical software packages used for this analysis was SPSS 16.0.

We used non-metric multidimensional scaling (NMS) to examine the relationship between species composition and forest structure among forest types. This multivariate analysis technique, performed in PC-ORD5, identifies correlations in the plot level and compositional data for each of the 41 survey plots, and relies on a similarity matrix created using the Sorensen (Bray-Curtis) index. NMS scales multi-dimensional data points for 41 survey sites by rank ordering raw counts of tree species presence (species with $<4$ individuals surveyed were excluded) and 7 survey plot ( 0.5 ha) level explanatory variables (number of trees, number of trees $\geq 20 \mathrm{~m}$, species richness, number of endemic trees, endemic species richness, number of Maesopsis eminii, and percent Maesopsis eminii). The NMS scaling was employed using random starting coordinates with 200 iterations and Sørensen distance measures to determine the pair-wise distances between species composition for each plot with respect to the plot level variables.

\section{Results}

Species Richness, Endemism, and Structure

A total of 194 tree species representing 63 families were found in 41 sites in upland East Usambaras. There were
10,837 stems measured with 10,799 stems identified to species, $15(0.03 \%)$ could be identified only to genus. A total of 164 species were found in mature secondary forest and natural forest, while 139 species were found in active agroforests and recently abandoned agroforests. The most diverse site (61 species) is located in the center of one of the largest forest patches under ownership of the East Usambara Tea Company. The least diverse site (22 species), occurring a kilometer away, is an active agroforest.

There were 17 tree species identified in the survey that are strictly endemic to the Eastern Arc humid forests of East Africa (Table 1). The mean number of endemic species that occur in a 0.5 ha plot in each of the forest classes is as follows: active agroforest 2.2 (SD 1.0), abandoned agroforest 3.3 (SD 1.4), mature secondary 6.3 (SD 2.5), and natural forest 5.4 (SD 1.3).

Mean values per survey plot were significantly different among the forest classes for species richness, endemic species richness and family richness (Table 2). Natural and mature secondary forests had higher mean values than active agroforest, but were not higher than abandoned forests. Active agroforests and abandoned agroforests were significantly different in species and family richness, but not different in endemic species richness. Abandoned agroforests were not significantly different from mature secondary and natural forests for species or family richness, but were different in endemic species richness.

The mean values of each forest class for survey plot values of number of trees, number of Maesopsis eminii, and number of endemic trees was significantly different among forest classes (Table 3). The mean values for active 
Table 2 Mean species richness, family richness, and endemic richness from 0.5 ha plots in the East Usambaras

Forest type: Ac: Active; Ab: Abandoned; Ms: Mature Secondary; Nt: Natural

a Variance similar, Gabriel's Post Hoc test used

b Variance statistically different, Games-Howell Post Hoc test used

c The mean difference is significant at the 0.05 level

\begin{tabular}{|c|c|c|c|c|}
\hline Forest type & & Species richness ${ }^{\mathrm{a}}$ & Family richness $^{\mathrm{a}}$ & Endemic richness ${ }^{\mathrm{b}}$ \\
\hline Ac $(n=9)$ & Mean (SD) & $26(3)$ & $20(2)$ & $2.2(1.0)$ \\
\hline $\mathrm{Ab}(n=13)$ & & $38(8)$ & $27(3)$ & $3.3(1.4)$ \\
\hline Ms $(n=9)$ & & $44(11)$ & $29(4)$ & $6.3(1.3)$ \\
\hline $\mathrm{Nt}(n=10)$ & & $40(7)$ & $29(3)$ & $5.4(2.5)$ \\
\hline ANOVA & & 9.31 & 15.26 & 12.11 \\
\hline$F_{2.86}=$ & & $P<0.0001$ & $P<0.0001$ & $P<0.0001$ \\
\hline \multicolumn{5}{|c|}{ Post Hoc comparison of means ${ }^{\mathrm{a}, \mathrm{b}}$} \\
\hline \multirow[t]{3}{*}{ Ac } & $\mathrm{Ab}$ & $-12.38^{\mathrm{c}}$ & $-6.78^{\mathrm{c}}$ & -1.09 \\
\hline & Ms & $-18.33^{\mathrm{c}}$ & $-8.88^{\mathrm{c}}$ & $-4.11^{\mathrm{c}}$ \\
\hline & $\mathrm{Nt}$ & $-13.06^{\mathrm{c}}$ & $-8.05^{\mathrm{c}}$ & $-3.18^{\mathrm{c}}$ \\
\hline \multirow[t]{3}{*}{$\mathrm{Ab}$} & $\mathrm{Ac}$ & $12.38^{\mathrm{c}}$ & $6.78^{\mathrm{c}}$ & 1.09 \\
\hline & Ms & -5.94 & -2.10 & $-3.03^{\mathrm{c}}$ \\
\hline & $\mathrm{Nt}$ & -1.21 & -1.26 & -2.09 \\
\hline \multirow[t]{3}{*}{ Ms } & Ac & $18.33^{\mathrm{c}}$ & $8.88^{\mathrm{c}}$ & $4.11^{\mathrm{c}}$ \\
\hline & $\mathrm{Ab}$ & 5.94 & 2.10 & $3.03^{\mathrm{c}}$ \\
\hline & $\mathrm{Nt}$ & 4.73 & 0.83 & 0.93 \\
\hline \multirow[t]{3}{*}{$\mathrm{Nt}$} & $\mathrm{Ac}$ & $13.60^{\mathrm{c}}$ & $8.05^{\mathrm{c}}$ & $3.18^{\mathrm{c}}$ \\
\hline & $\mathrm{Ab}$ & 1.21 & 1.26 & 2.09 \\
\hline & Ms & -4.73 & -0.83 & -0.93 \\
\hline
\end{tabular}

Table 3 Mean number of stems from sites in the East Usambaras

\begin{tabular}{|c|c|c|c|c|c|c|c|}
\hline $\begin{array}{l}\text { Forest Class } \\
(N)\end{array}$ & & $\begin{array}{l}\text { Stems } \\
<20 \mathrm{~m}^{\mathrm{a}}\end{array}$ & $\begin{array}{l}\text { Stems } \\
>20 \mathrm{~m}^{\mathrm{b}}\end{array}$ & $\begin{array}{l}\text { Prop M. eminii } \\
<20 \mathrm{~m}^{\mathrm{a}}\end{array}$ & $\begin{array}{l}\text { Prop } M . \text { eminii } \\
>20 \mathrm{~m}^{\mathrm{a}}\end{array}$ & $\begin{array}{l}\text { Endemic stems } \\
<20^{\mathrm{a}}\end{array}$ & $\begin{array}{l}\text { Endemic stems } \\
>20^{\mathrm{a}}\end{array}$ \\
\hline Ac $(n=9)$ & \multirow{6}{*}{$\begin{array}{l}\text { Mean } \\
\text { (SD) }\end{array}$} & $45(27)$ & $69(26)$ & $0.20(0.20)$ & $0.26(0.26)$ & $1.1(1.5)$ & $2.6(1.8)$ \\
\hline $\mathrm{Ab}(n=13)$ & & $153(61)$ & $142(56)$ & $0.10(0.09)$ & $0.32(0.17)$ & $7.8(5.3)$ & $4.3(3.1)$ \\
\hline Ms $(n=9)$ & & $163(70)$ & $172(65)$ & $0.02(0.02)$ & $0.30(0.07)$ & $23.2(12.9)$ & $11.2(7.2)$ \\
\hline $\mathrm{Nt}(n=10)$ & & $146(84)$ & $136(46)$ & $0.01(0.01)$ & $0.06(0.05)$ & $22.3(14.5)$ & $12.1(10.4)$ \\
\hline ANOVA & & 6.76 & 6.6 & 6.27 & 9.54 & 12.71 & 5.5 \\
\hline$F_{2.86}=$ & & $P<0.0001$ & $P<0.001$ & $P=0.001$ & $P=0.001$ & $P<0.0001$ & $P=0.003$ \\
\hline \multicolumn{8}{|c|}{ Post Hoc comparison of means $\mathrm{s}^{\mathrm{a}, \mathrm{b}}$} \\
\hline \multirow[t]{3}{*}{ Ac } & $\mathrm{Ab}$ & $-107.97^{\mathrm{c}}$ & $-73.27^{\mathrm{c}}$ & $0.10^{\mathrm{c}}$ & -0.05 & $-6.74^{\mathrm{c}}$ & -1.75 \\
\hline & Ms & $-117.56^{\mathrm{c}}$ & $-103.00^{\mathrm{c}}$ & $0.18^{\mathrm{c}}$ & -0.03 & $-22.01^{\mathrm{c}}$ & $-8.67^{\mathrm{c}}$ \\
\hline & $\mathrm{Nt}$ & $-100.89^{c}$ & $-66.49^{c}$ & $0.19^{c}$ & 0.20 & $-22.69^{c}$ & -9.54 \\
\hline \multirow[t]{3}{*}{$\mathrm{Ab}$} & $\mathrm{Ac}$ & $107.97^{\mathrm{c}}$ & $73.27^{\mathrm{c}}$ & $-0.10^{\mathrm{c}}$ & 0.05 & $6.74^{\mathrm{c}}$ & 1.75 \\
\hline & Ms & -9.59 & -29.73 & 0.07 & 0.02 & $-15.26^{\mathrm{c}}$ & -6.91 \\
\hline & $\mathrm{Nt}$ & 7.08 & 6.78 & 0.08 & $0.26^{\mathrm{c}}$ & $-15.95^{\mathrm{c}}$ & -7.79 \\
\hline \multirow[t]{3}{*}{ Ms } & $\mathrm{Ac}$ & $117.56^{\mathrm{c}}$ & $103.00^{\mathrm{c}}$ & $-0.18^{\mathrm{c}}$ & 0.03 & $22.01^{\mathrm{c}}$ & $8.67^{\mathrm{c}}$ \\
\hline & $\mathrm{Ab}$ & 9.59 & 29.73 & -0.07 & -0.02 & $15.26^{\mathrm{c}}$ & 6.91 \\
\hline & $\mathrm{Nt}$ & 16.67 & $36.51^{\mathrm{c}}$ & 0.01 & $0.24^{\mathrm{c}}$ & -0.69 & -0.88 \\
\hline \multirow[t]{3}{*}{$\mathrm{Nt}$} & $\mathrm{Ac}$ & $100.89^{c}$ & $66.49^{c}$ & $-0.19^{\mathrm{c}}$ & -0.20 & $22.69^{c}$ & 9.54 \\
\hline & $\mathrm{Ab}$ & -7.08 & -6.78 & -0.08 & $-0.26^{\mathrm{c}}$ & $15.95^{\mathrm{c}}$ & 7.7 \\
\hline & Ms & -16.67 & -36.51 & -0.01 & $-0.24^{\mathrm{c}}$ & .689 & 0.88 \\
\hline
\end{tabular}

Surveyed area 0.5 ha for trees $\geq 20 \mathrm{~m}, 0.1$ ha for trees $<20 \mathrm{~m}$. Species endemic to the Eastern Arc. Forest type: Ac: Active; Ab: Abandoned; Ms: Mature Secondary; Nt: Natural

a Variance statistically different, Games-Howell Post Hoc test used

b Variance similar, Gabriel's Post Hoc test used

${ }^{c}$ The mean difference is significant at the 0.05 level 
agroforest were statistically lower than those of the other three forest classes for number of trees $\geq$ and $<20 \mathrm{~m}$, proportion of stems $<20 \mathrm{~m}$ that are Maesopsis eminii, and the number of endemic species. The mean number of endemic trees $<20 \mathrm{~m}$ and $\geq 20 \mathrm{~m}$ in active agroforests was 1 and 3, compared to the mean number of endemic stems in natural forest (22 and 12) and mature secondary forest plots (23 and 1). Active agroforests average 1 endemic tree $<20 \mathrm{~m}$ per 0.1 ha and nine active agroforests contained no endemic trees $<20 \mathrm{~m}$ while all mature secondary and natural forests contained endemic stems in the $<20 \mathrm{~m}$ height class and averaged 23 and 22 trees per 0.1 ha, respectively.

The test did not find the mean values of the forest classes significantly different for proportion of trees $\geq 20 \mathrm{~m}$ that are Maesopsis eminii although the proportion in natural forest $(0.06)$ is discernibly lower than the three other forest classes: active 0.26 , abandoned 0.32 , and mature secondary 0.30 . This is due to the large standard deviation of proportion Maesopsis eminii in active agroforests (SD 0.28). Abandoned agroforests mean values were statistically different from active agroforests in most measures. Abandoned agroforests were similar to mature secondary and natural forests in number of trees $\geq$ and $<20 \mathrm{~m}$, and proportion of Maesopsis eminii $<20 \mathrm{~m}$, yet were different for mean number of endemic trees $<20 \mathrm{~m}$.

Examination of the mean number of stems and species richness values for the four classes of forest reveals the same pattern (Fig. 2a-c). Richness and number of stems is lower in shade grown crop farms, much higher in abandoned agroforests and natural forest, and is greatest in mature secondary forests. We found no significant difference between natural and mature secondary forest trees $<20 \mathrm{~m}$ and trees $\geq 20 \mathrm{~m}$ for species richness, number of stems, and number of endemic stems, and only a statistically significant difference between the two for proportion of Maesopsis eminii $\geq 20 \mathrm{~m}$ (Tables 2 and 3).

\section{Invasive Non-Native Species}

Maesopsis eminii accounted for $16 \%$ of all stems measured and is the most common species in this survey. It is dominant in active agroforests, abandoned farms, and mature secondary forest and is more prominent in taller classes of trees. Active agroforests, abandoned agroforests, and mature secondary forests have a large percent of taller trees ( $\geq 20 \mathrm{~m}$ ) that are Maesopsis eminii (Fig. 3), and this nonnative constitutes nearly $50 \%$ of all stems $30-50 \mathrm{~m}$ in these three forest types. Active agroforests have on average only a third of the number of trees as other forest classes, yet $20 \%$ of these trees are Maesopsis eminii. In active agroforests, $28 \%$ of stems $<10 \mathrm{~m}$ are Maesopsis eminii, while in natural and mature secondary forest $<1 \%$ stems of these young stems are Maesopsis eminii. Recently abandoned
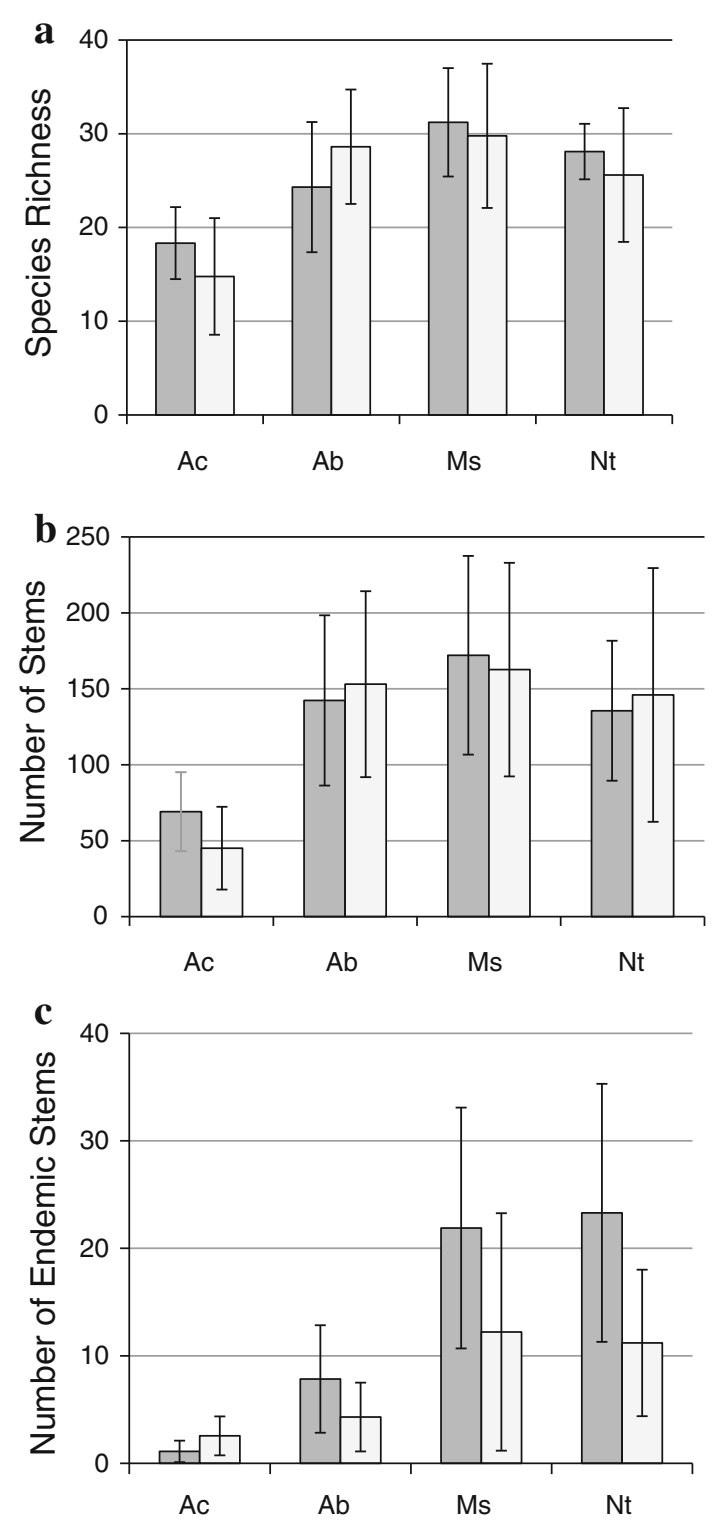

Fig. 2 a Mean species richness, b Mean number of stems surveyed, c Mean number of stems of species endemic to the Eastern Arc Mountains. Forest classes: 9 active cardamom agroforests (Ac), 13 abandoned agroforests (Ab), 9 mature secondary forests (Ms), and 10 nature forests $(\mathrm{Nt})$. Dark grey bars are trees $<20 \mathrm{~m}$ tall $(0.1$ ha surveyed). Light grey bars are trees $\geq 20 \mathrm{~m}$ tall ( 0.5 ha surveyed)

agroforests have a high density of trees, yet many of these trees are Maesopsis eminii. Recently abandoned agroforests have similar numbers of trees in each height class as natural forests, yet in abandoned agroforests, $32 \%$ of trees $\geq 20 \mathrm{~m}$ are Maesopsis eminii, while the non-native makes up only $6 \%$ of trees $\geq 20 \mathrm{~m}$ in natural forest.

\section{Forest Composition}

The ordination results are displayed in the biplot graph of the two ordination axes produced by the NMS. The two 


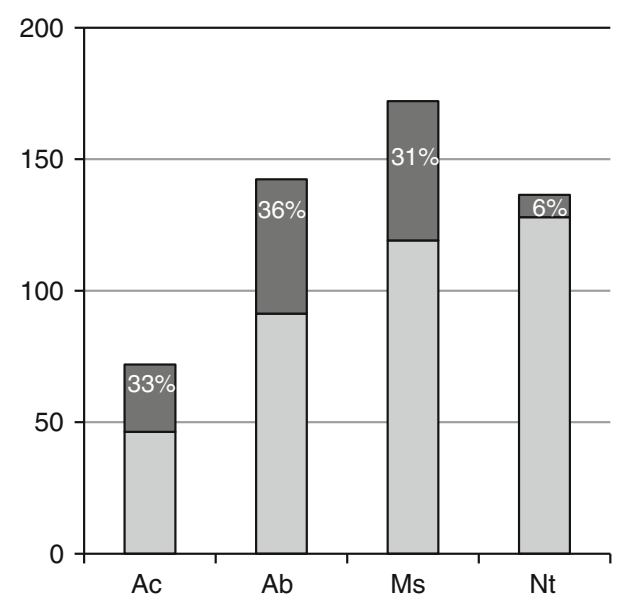

Fig. 3 Average number of stems $>20 \mathrm{~m}$ per forest class. Black bars are average numbers of Maesopsis eminii, and light grey bars are average numbers of stems of other species

highly orthogonal axes (95\%) together explain $92 \%$ of the cumulative observed variance in the floristic and plot level data (Fig. 4). The NMS recommended a two dimensional solution with a final stress value of 11.22. The final standard deviation of stress values was $<0.001$, which suggests that the test performance was good (McCune and Mefford 1999; McCune and Grace 2002).

The newly generated variable, Axis 1 , was highly correlated with richness (0.774) and number of stems (0.949) (Table 4). This axis, which explains $85 \%$ of the variance in the data, demonstrates the divergence between the less dense and less species rich agroforests that are routinely cleared of saplings and of some canopy trees, and the other three protected forest types which have more trees with higher species richness. Axis 2 explains $7 \%$ of the variance in the data and was highly correlated with number of Maesopsis eminii (0.843). This axis represents a gradient from fewest Maesopsis eminii in the natural forest and a higher proportion in mature secondary forest and abandoned agroforests.

In the NMS biplot, the horizontal direction of the arrows representing species richness and number of stems are perpendicular to the vertical direction of the arrows representing the presence of Maesopsis eminii. The perpendicular pattern shows that presence of Maesopsis eminii does not have a strong association in these forests with species richness and number of stems. Although mature secondary forests have more stems and species than natural forest, they also have a much higher proportion of Maesopsis eminii. This difference between natural and mature secondary forest was represented in their relative positions in the NMS biplot respective to the $\mathrm{Y}$ axis.

The scatter plot from the ordination illustrates that active agroforests are far removed floristically from other forest types and from each other (Fig. 4). ANOVA results show that the four classes of forests have statistically different mean scores for Axis $1\left(F_{2.86}=16.7\right)$ and Axis 2 $\left(F_{2.86}=4.2\right)$. Comparing the positions of active agroforests to those of the individual species demonstrates that there is no one suite of species that make up the residual trees in the active agroforests canopy.

Active agroforests differ from all other forest classes in terms of number of stems and natural forests differ from all other forest classes in terms of number of Maesopsis eminii (Fig. 4). Axis 1 relates highest to number of stems, and the mean Axis 1 NMS scores were positive for all forest classes except agroforest, relating to their low number of trees. Axis 2 relates highest to number of Maesopsis eminii and the mean Axis 2 NMS scores were positive for all forest classes, except for natural forests, relating to their very low proportions of Maesopsis eminii. Axis 1 scores for agroforests were statistically different $(P \leq 0.01)$ from all other forest classes, relating to their low species richness and number of trees compared to all other forest classes. Axis 2 scores for natural forest and mature secondary forests were statistically different $(P=0.00)$.

\section{Discussion}

Species Richness and Endemism

This research demonstrates that important differences occur between East Usambara humid forests under different past and present management regimes. Traditional agroforests can have significant numbers of tree species; although levels of species richness and endemic species richness are significantly lower than those of natural or mature secondary forest. Our results support Huang and others (2003) and confirm that mature secondary forests, which were mechanically selectively logged in the past, today have similar species richness levels as natural forests.

Many Eastern Arc endemic species are not disturbance or habitat generalists and require closed canopy forest. Trees endemic to the Eastern Arc are mostly found in undisturbed sites with closed canopy forest (Hamilton and Bensted-Smith 1989). Because large trees are reproductively dominant (Richards 1996), the significant number of large endemic trees in natural forest emphasizes the importance of their conservation. Studies from agroforestry landscapes throughout the tropics agree that species richness is higher when agroforests are under 'traditional' low intensity management, where the diversity of native trees in the canopy is high, understory clearing is not intense, and no chemical inputs are used (Perfecto and Armbrecht 2003; Perfecto and others 2003; Bhagwat and others 2008). While 'traditional' agroforests can have significant biodiversity values, biological integrity of the forest declines 


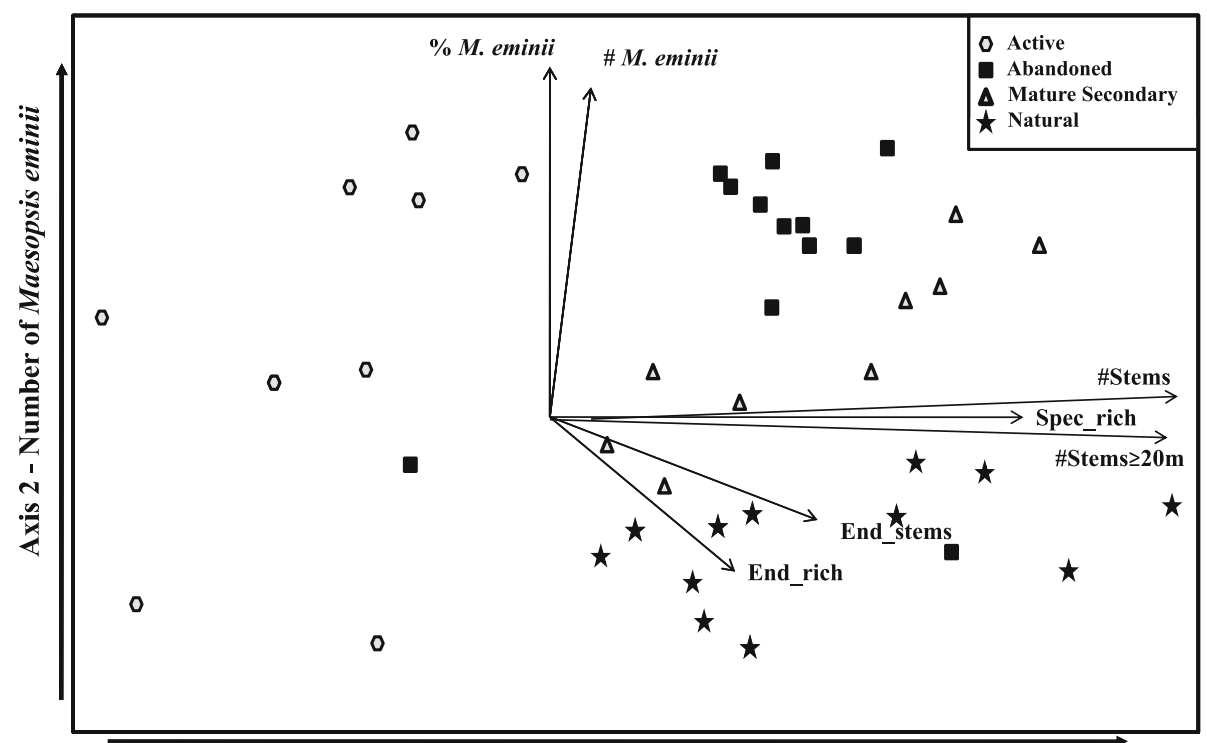

Axis 1 - Number of trees and species

Fig. 4 Biplot rendered by the nonmetric multi-dimensional scaling showing ordination of 41 sites on Axis 1, correlating with species richness (0.749) and stem density (0.942) and Axis 2 correlating with presence of Maesopsis eminii (0.844). Total species richness (Tot_Rich), total number of trees (\#Stems), number of trees over $20 \mathrm{~m}$ (\#Stems $\geq 20 \mathrm{~m}$ ), richness of endemic species (End_rich),

Table 4 Pearson's correlation coefficients of the plot level data, and Axes 1 and 2 produced with the non-metric multidimensional scaling ordination

\begin{tabular}{lcr}
\hline Pearson correlation & Axis 1, $r$ & Axis 2, $r$ \\
\hline Number of trees & 0.949 & 0.165 \\
Number of trees $>20 \mathrm{~m}$ & 0.896 & -0.005 \\
Species richness & 0.774 & 0.112 \\
Endemic richness & 0.421 & -0.434 \\
Number of endemic trees & 0.470 & -0.158 \\
Percent stems M. eminii & -0.105 & 0.738 \\
Number of M. eminii & 0.360 & 0.843 \\
\% Variance explained & $85 \%$ & $7 \%$ \\
\hline
\end{tabular}

Endemic richness refers to species endemic to the Eastern Arc Mountains

quickly as management of the agroforest intensifies and as years under cultivation increase (Martinez and Peters 1996).

This study complements that of Newmark (2002) who found that protecting primary forest is essential for conserving the biological richness of the Eastern Arc. Although there were high levels of tree species richness in traditional agroforests, this does not suggest that cardamom agroforests will in the future maintain this diversity if farmers increase management intensity and as the amount of forest in the surrounding landscape decreases. The results of this study also do not imply that agroforests number of Maesopsis. eminii trees (\# M. eminii), and percent of stems being Maesopsis eminii (\% M. eminii). Forest classes: active agroforest, abandoned agroforest, mature secondary, natural forest. The position of the grey dots indicates the graph scores of individual species relative to each axis

function as adequate biodiversity corridors for any taxa. The forest understory is completely removed even in traditional agroforests, and the understory contains a large proportion of the species and endemic richness in Eastern Arc forest (Hamilton \& Bensted-Smith 1989).

\section{Floristic Composition and Structure}

The amount of forest in the surrounding landscape may influence the diversity in regenerating abandoned agroforests. The current landscape maintains significant areas of mature secondary forest, which are privately owned and not part of the national protected area system. The results of this study may be different in a landscape with little or no mature forest. Although the number of Maesopsis eminii is high in abandoned farms, species richness of native forest trees is also high, and other studies have suggested it will continue to increase (Binggeli 1989; Hamilton and Bensted-Smith 1989). Approximately 820 ha of agroforests have entered into protected areas in the East Usambaras within the past decade (J. Hall, Unpublished results). Mature secondary forests are private and strictly protected by tea estate guards who are known to use force when estate property of any kind is trespassed. This suggests that the strict level of protection has allowed mature secondary forests to flourish.

Ten of the thirteen abandoned agroforests in this study have been placed within some form of protected area, 
either in a small village forest reserves or inside the new Derema Government Forest Reserve. Farmers of cardamom and other crops were asked to stop maintaining their plots within the Derema ridge in 2002 (Aaronson 2006). The data from this study suggest abandoned agroforests can have high numbers of species and large number of trees, however, in the future levels of species richness will depend on the level of protection.

\section{Non-Native Species}

One of the most important variables related to the floristic composition of the forests, demonstrated by Axis 2, is the number of Maesopsis eminii. The current composition and structure may be shaped heavily by the past disturbance that allowed Maesopsis eminii to become established. Only non-native trees can be legally harvested in the Eastern Arc and Maesopsis eminii grows abundantly without assistance. The felling of Maesopsis eminii, opens new canopy gaps and causes damage to the adjacent forest, creating a situation where Maesopsis eminii becomes dominant over time (Binggeli 1989; Viisteensaari and others 2000). As a consequence, it was the most common tree surveyed in this study.

Almost a third of the taller trees in active agroforests are Maesopsis eminii. The dominance of this species may be influenced by two processes. First, its habit of out-competing native species in disturbed areas where the canopy is open. Second, it has been suggested that national forest policies restricting the use of native montane rain forest trees may influence the decisions farmers make regarding maintenance of the tree canopy in their agroforests (S. Rantala personal communication). It is currently illegal to sell or make timber from a native hardwood tree, but Maesopsis eminii can be legally used and sold (usually as fire wood to tea and soap factories). Thus, farmers may prefer to allow the non-native Maesopsis eminii to regenerate in place of native trees.

Maesopsis eminii represents $16 \%$ of all stems measured and was found in all sites except one location at the top of the western ridge within Nilo Government Forest Reserve. Maesopsis eminii seedlings can germinate in closed forest, but will not mature due to the lack of sunlight. Maesopsis eminii trees grow tall quickly when there is a gap allowing light to lower levels. Young trees can grow $3 \mathrm{~m}$ a year (Binggeli 1989), and mature secondary forest contains a high number of large Maesopsis eminii in the canopy. The number of endemic stems $\geq 20 \mathrm{~m}$ was greater in natural forest than mature secondary, and this pattern is likely influenced by the large number of Maesopsis eminii in mature secondary forest.

Maesopsis eminii makes up $37 \%$ of taller trees in active agroforests and active agroforests were the only forest type with high numbers of Maesopsis eminii in the $<10 \mathrm{~m}$ height class. This species can only regenerate within actively disturbed forest. Once the forest closes, Maesopsis eminii will no longer compete in the seedling layer. However, Maesopsis eminii is a long lived tropical species that will remain dominant in the canopy of mature forest, demonstrated by the high number of $\geq 20 \mathrm{~m}$ Maesopsis eminii in all forest types except natural (Binggeli 1989).

The authors recognize that several limitations to this study exist. This study used large plots and measured saplings in order to capture the natural variability of the humid forest ecosystem. Due to the time required to complete each plot the number of plots is not as high as we would have liked. In addition we do not have information from each plot that would allow for the analysis of the regeneration of abandoned forests. Resurveying of all abandoned plots is planned for 2011 which will be five year post the initial survey.

\section{Environmental Management Implications}

Cardamom has been a valuable part of a diversified farming strategy in the East Usambaras for 50 years (Reyes and others 2006). However, cardamom agroforestry is often not a permanent land cover, and is frequently the initial phase of Eastern Arc forest clearance. There are currently several institutions researching methods to increase cardamom agroforestry as a more sustainable and ecologically appropriate crop system compared to sun grown crops. The farmers of the East Usambaras would likely increase agroforestry practices if the price for cardamom was more stable (Theron Morgan-Brown Personal communication). Coupled with current tree planting incentives sponsored by locally active conservation NGO's, Tanzania Forest Conservation Group and WWF Tanzania, cardamom agroforest establishment on deforested slopes could be a positive trend in the East Usambaras, which has had 13,000 ha of forest cleared between 1992 and 2006 (J. Hall unpublished data).

There are three concerns pertaining to the current and future role of agroforestry in the conservation of Eastern Arc forest. First, overtime, continued opening of the canopy will favor the dominance of the non-native Maesopsis eminii, and compositional and structural diversity will decrease. Second, a more profitable cardamom market would be beneficial to local farmers and could encourage agroforestry establishment in currently deforested areas, but could also lead to expansion of cultivation into protected areas, as has occurred in the Nguru South Forest Reserve. Therefore, any effort to encourage cardamom farming must be coupled with increased monitoring of forest reserves. Third, will continued human population increase lead to increased management intensity and likely 
reduce the effectiveness of agroforests as habitat for forest species? The absence of young endemic trees in two thirds of the active agroforests sites brings into question the ability of the agroforestry production system to contribute to the conservation goals of the East Usamabaras, where protecting habitat for endemic species is one of the most important conservation objectives (http://www.easternarc. or.tz).

Research from agroforestry systems throughout the world has found that a greater diversity of tree species and complexity of structure in the shade canopy will support a greater diversity in other biological taxa (Greenberg and others 1997; Reyes and others 2006; Philpott and others 2008). When an agroforest is prepared out of a native forest, the initial species and structural diversity in the agroforest canopy can be high, as is the case in many of the active and abandoned agroforests in the East Usambaras. After many years of maintenance by the farmer, the species and structural diversity usually diminishes. However, if tree canopies are maintained with diverse native trees, some limited aspects of native species richness of other taxa could persist in an agroforest, even when managed for crop production beneath (Greenberg and others 1997; Cockle and others 2005; Reyes and others 2006; Harvey and González Villalobos 2007). New agroforests established in deforested areas would increase important ecosystem services to the region, provide a potential avenue for carbon sequestration payments to reach farmers, as well as supply local families with many forest products, thus relieving pressure from the forest reserves (Murniati and others 2001; Huang and others 2002). Encouragement of the use of diverse native trees and the establishment of new agroforest areas should be combined with increased monitoring of protected areas and extension of reserves to include important corridors. In this manner, agroforestry using diverse native tree canopies could be successfully integrated into a landscape scale conservation plan for the East Usambaras.

Acknowledgments The data collection that led to this paper was supported by Conservation International and the Critical Ecosystem Partnership Fund, Fulbright, and NSF IGERT Working Forests in the Tropics. The project was organized with logistical support and from Tanzania Forest Conservation Group and WWF Tanzania. Moses Mwangoka was supported by Tanzania Forest Conservation Group. Special thanks are given to Nike Doggart for valuable advice. Boniface Mtui assisted with logistics in the field. Jaclyn Hall was also supported by Fulbright, the Critical Ecosystems Partnership Fund, and the American Association of University Women. The authors thank G. Schroth, R. Gereau, N. Cordeiro, and one anonymous reviewer for the many helpful comments and suggestions.

Open Access This article is distributed under the terms of the Creative Commons Attribution Noncommercial License which permits any noncommercial use, distribution, and reproduction in any medium, provided the original author(s) and source are credited.

\section{References}

Aaronson D (2006) Resettlement action plan for farm plots displaced for biodiversity conservation in the Derema forest corridor. Ministry of Natural Resources and Tourism, Forestry and Beekeeping Division, Dar es Salaam, Tanzania. Available at: http:// easternarc.or.tz/downloads/East-Usambara/DeremaResettlement ActionPlanEnglishversion.pdf

Achard F, Eva HD, Stibig HJ, Mayaux P, Gallego J, Richards T, Malingreau JP (2002) Determination of deforestation rates of the world's humid tropical forests. Science 297:999-1002

Bhagwat SA, Willis KJ, Birks HJB, Whittaker RJ (2008) Agroforestry: a refuge for tropical biodiversity? Trends in Ecology and Evolution 23:261-266

Binggeli P (1989) The ecology of Maesopsis invasion and dynamics of the evergreen forest of the East Usambaras, and their implications for forest conservation and forestry practices. In: Hamilton AC, Bensted-Smith R (eds) Forest conservation in the East Usambara Mountains, Tanzania. IUCN, Gland, pp 269-300

Bishop J, Landell-Mills N (2002) Forest Environmental Services: An Overview. In: Pagiola S, Bishop J, Landell-Mills N (eds) Selling Forest Environmental Services. Earthscan, London, p 299

Borghesio L, John JRM, Mulungu E, Mkongewa V, Joho M, Cordeiro NJ (2008) Observations of threatened birds in the East Usambara Mountains, Tanzania. Bulletin of the African Bird Club 15:59-70

Brooks TM, Mittermeier RA, Mittermeier CG, da Fonseca GAB, Rylands AB, Konstant WR, Flick P, Pilgrim J, Oldfield S, Magin G, Hilton-Taylor C (2002) Habitat loss and extinction in the hotspots of biodiversity. Conservation Biology 16:909-923

Burgess ND, Butynski TM, Cordeiro NJ, Doggart NH, Fjeldsa J, Howell KM, Kilahama FB, Loader SP, Lovett JC, Mbilinyi B, Menegon M, Moyer DC, Nashanda E, Perkin A, Rovero F, Stanley WT, Stuart SN (2007) The biological importance of the Eastern Arc Mountains of Tanzania and Kenya. Biological Conservation 134:209-231

Cockle KL, Leonard ML, Bodrati AA (2005) Presence and abundance of birds in an Atlantic forest reserve and adjacent plantation of shade-grown yerba mate in Paraguay. Biodiversity and Conservation 14:3265-3288

Greenberg R, Bichier P, Angon AC, Reitsma R (1997) Bird populations in shade and sun coffee plantations in Central Guatemala. Conservation Biology 11:448-459

Hall JB (1995) Maesopsis eminii and its status in the East Usambara Mountains, technical paper 13. Ministry of Tourism, Natural Resources and Environment, Tanzania. Available at: http:// easternarc.or.tz/downloads/E-Usam/EUCAMP/tecpap13.pdf

Hall JM, Burgess N, Lovett J, Mbilinyi B, Gereau R (2009) Conservation implications of deforestation across an elevational gradient in the Eastern Arc Mountains, Tanzania. Biological Conservation 142:2510-2521

Hamilton AC, Bensted-Smith R (1989) Forest conservation in the East Usambara Mountains, Tanzania. World Conservation Union, Gland

Harvey CA, González Villalobos JA (2007) Agroforestry systems conserve species-rich but modified assemblages of tropical birds and bats. Biodiversity and Conservation 16:2237-2244

Huang WD, Pohjonen V, Johansson S, Nashanda M, Katigula MIL, Luukkanen O (2003) Species diversity, forest structure and species composition in Tanzanian tropical forests. Forest Ecology and Management 173:11-24

Huang W, Luukkanen O, Johanson S, Kaarakka V, Räisänen S, Vihemäki H (2002) Agroforestry for biodiversity conservation of nature reserves: functional group identification and analysis. Agroforestry Systems 55:65-72 
Lovett J, Wasser SK (1993) Biogeography and ecology of the rain forests of eastern Africa. Cambridge University Press, Cambridge

Martinez E, Peters W (1996) La cafeticultura biológica: la finca Irlanda como estudio de caso de un disenio agroecológico. In: Trujillo J, de León-Gonzalez F, Calderón R, Torres-Lima P (eds) Ecologia aplicada a la agricultura:t emas selec-tos de Mexico. UniversidadA utónoma Metroplitana, Mexico, D.F., pp 159-183

McCune B, Mefford MJ (1999) Multivariate analysis of ecological data version 4.19. MjM Software Design, Gleneden Beach, OR

McCune B, Grace JB (2002) Analysis of ecological communities. MjM Software Design, Gleneden Beach

Moguel P, Toledo VM (1999) Biodiversity conservation in traditional coffee systems of Mexico. Conservation Biology 13:11-21

Myers N, Mittermeier RA, Mittermeier CG, da Fonesca GAB, Kent J (2000) Biodiversity hotspots for conservation priorities. Nature 403:853-858

Murniati D, Garrity P, Ginting Ng (2001) The contribution of agroforestry systems to reducing farmers' dependence on the resources of adjacent national parks: a case study from Sumatra, Indonesia. Agroforestry Systems 52:171-184

Newmark WD (1991) Tropical forest fragmentation and the local extinction of understory birds in the Eastern Usambara Mountains, Tanzania. Conservation Biology 5:67-78

Newmark WD (1998) Forest area, fragmentation, and loss in the Eastern Arc Mountains: implications for the conservation of biological diversity. Journal of the East African Natural History Society $87: 29-36$

Newmark WD (2002) Conserving biodiversity in East African Forests: a study of the Eastern Arc Mountains. Ecological studies, vol 155. Springer, Berlin

Newmark WD (2006) A 16-year study of forest disturbance and understory bird community structure and composition in Tanzania. Conservation Biology 20:122-134

Perfecto I, Mas A, Dietsch T, Vandermeer J (2003) Conservation of biodiversity in coffee agroecosystems: a tri-taxa comparison in southern Mexico. Biodiversity and Conservation 12:1239-1252

Perfecto I, Armbrecht I (2003) Technological change and biodiversity in the coffee agroecosystem of Northern Latin America. In: Vandermeer J (ed) Tropical agroecosystems. CRC Press LLC, Boca Raton, pp 159-194

Philpott SM, Armbrecht I (2006) Biodiversity in tropical agroforests and the ecological role of ants and ant diversity in predatory function. Ecological Entomology 31:369-377

Philpott SM, Arendt W, Armbrecht I, Bichier P, Dietsch T, Gordon C, Greenberg R, Perfecto I, Soto-Pinto L, Tejeda-Cruz C, Williams G, Valenzuela J (2008) Biodiversity loss in Latin American coffee landscapes: review of the evidence on ants, birds, and trees. Conservation Biology 22:1093-1105

Pócs T (1976) Vegetation mapping in the Uluguru Mountains (Tanzania, East Africa). Boissera, pp 477-498

Rappole JH, King DI, Rivera JHV (2003) Coffee and conservation. Conservation Biology 17:334-336

Reyes T, Luukkanen O, Quiroz R (2006) Small cardamom—precious for people, harmful for mountain forests. Mountain Research and Development 26:131-137

Reyes T (2005) Socio-economic comparison between traditional and improved cultivation methods in agroforestry systems, East Usambara Mountains, Tanzania. Environmental Management 36:682-690

Richards P (1996) The tropical rain forest, an ecological study. Cambridge University Press, Cambridge

Rotenberg JA (2007) Ecological role of a tree (Gmelina arborea) plantation in Guatemala: an assessment of an alternative land use for tropical avian conservation. The American Ornithologists' Union 124:316-330

Roth DS, Perfecto I, Rathcke B (1994) The effects of managementsystems on ground-foraging ant diversity in Costa Rica. Ecological Applications 4:423-436

Schroth G, da Fonseca GAB, Harvey CA, Gascon C, Vasconcelos HL, Izac AMN (2004) Agroforestry and biodiversity conservation in tropical landscapes. Island Press, Washington

Steffan-Dewenter I, Kessler M, Barkmann J, Bos M, Buchori D, Erasmi S, Faust H, Gerold G, Glenk K, Gradstein RS, Guhardja E, Harteveld M, Hertel D, Höhn P, Kappas M, Köhler S, Leuschner C, Maertens M, Marggraf R, Migge-Kleian S, Mogea J, Pitopang R, Schaefer M, Schwarze S, Sporn GS, Steingrebe A, Tjitrosoedirdjo SS, Tjitrosoemito $\mathrm{S}$, Twele A, Weber $\mathrm{R}$, Woltmann L, Zeller M, Tscharntke T (2007) Tradeoffs between income, biodiversity, and ecosystem functioning during tropical rainforest conversion and agroforestry intensification. Proceedings of the National Academy of Sciences 104:4973-4978

Tscharntke T, Kelin AM, Kruess A, Steffan-Dewenter I, Thies C (2005) Landscape perspectives on agricultural intensification and biodiversity-ecosystem servicemanagement. Ecology Letters 8:857-874

Turner WR, Brandon K, Brooks TM, Costanza R, da Fonseca GAB, Portela R (2007) Global conservation of biodiversity and ecosystem services. BioScience 57:868-873

Viisteensaari J, Johansson S, Kaarakka V, Luukkanen O (2000) Is the alien tree species Maesopsis eminii Engl. (Rhamnaceae) a threat to tropical forest conservation in the East Usambaras, Tanzania? Environmental Conservation 27:76-81 